\title{
ИЗУЧЕНИЕ ПРОИЗВОДНЫХ ТРИСИНДОЛИЛМЕТАНА КАК ПЕРСПЕКТИВНОЕ НАПРАВЛЕНИЕ ДЛЯ ПОИСКА ВЕЩЕСТВ С АНТИМИКРОБНОЙ И ПРОТИВООПУХОЛЕВОЙ АКТИВНОСТЬЮ
}

\section{С.Н.Лавренов}

ФГБНУ «Научно-исследовательский институт по изысканию новых антибиотиков имени Г.Ф. Гаузе», 119021, Россия, Москва, ул. Б. Пироговская, 11.

DOI: 10.19163/MedChemRussia2021-2021-33

E-mail: lavrenov@mail.ru

Производные трисиндолилметана, несмотря на хорошую синтетическую доступность, остаются относительно малоизученным классом соединений. Однако, большинство веществ, имеющих в структуре этот фрагмент, обладают цитотоксической активностью с разной степенью селективности по отношению к разным биологическим объектам. Основной мишенью их действия является клеточная мембрана, от конкретных свойств и структуры которой и зависит уровень воздействия на клетку. Нами был изучен ряд соединений этого типа с целью поиска среди них потенциальных антибактериальных, противогрибковых и противоопухолевых веществ, сочетающих высокую активность с относительно низкой токсичностью на здоровые клетки человека.
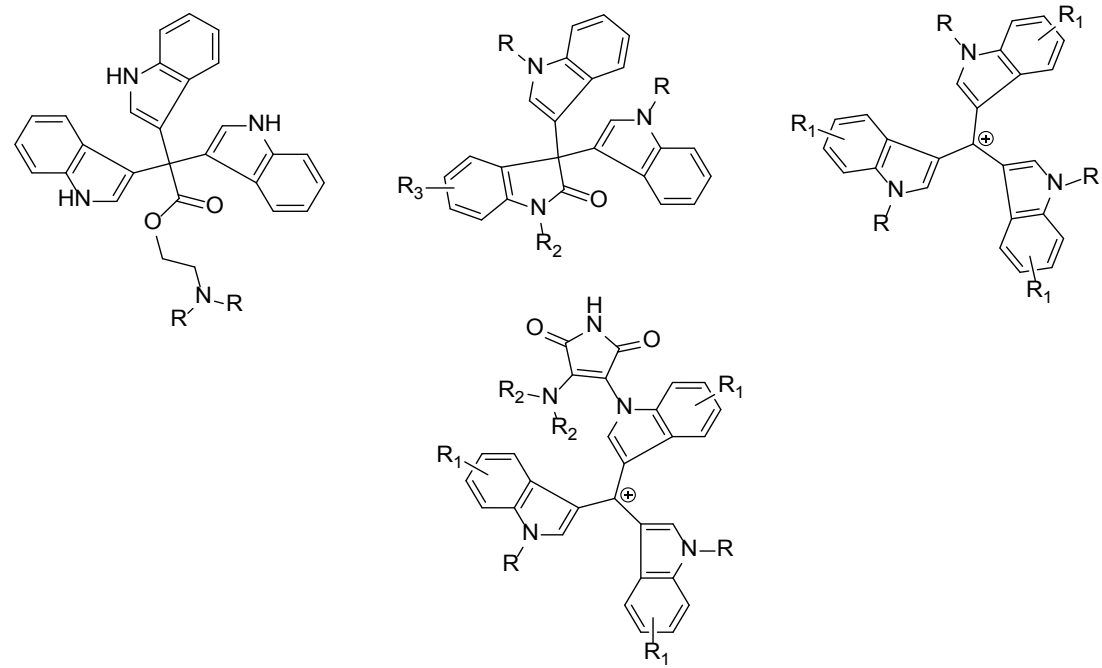

В работе получена и протестирована серия новых соединений, сделаны первичные выводы о связи структура - активность. 